\title{
The Institute of Human Palæontology, Paris.
}

$\mathrm{O}$ $\mathrm{N}$ December 23, I920, the Institute of Human Palæontology in Paris was formally declared open by His Serene Highness Prince Albert of Monaco, its founder. The interest and active participation of the Prince in more than one branch of research have long been highly appreciated by the scientific world. The study of marine biology and oceanography already owed much to his valuable assistance and support when, more than twenty years ago, a visit to the Grimaldi Cave at Mentone first turned his attention to prehistoric archæology. Since that time all the more important cave explorations in Southern France and Northern Spain, which have enabled ing, which was nearing completion when war broke out, contains a large amphitheatre for lectures and meetings, a spacious library, and a number of rooms fitted up as laboratories, for examining and photographing the material furnished by excavation. Collections of specimens from the sites which have already been explored, as well as reproductions of the paintings and drawings found on the walls of the French and Spanish palæolithic caves, are exhibited in the building. An endowment of two million francs is attached to the Prince of Monaco's foundation, and an additional sum has been promised should it be rendered necessary by any further increase in the

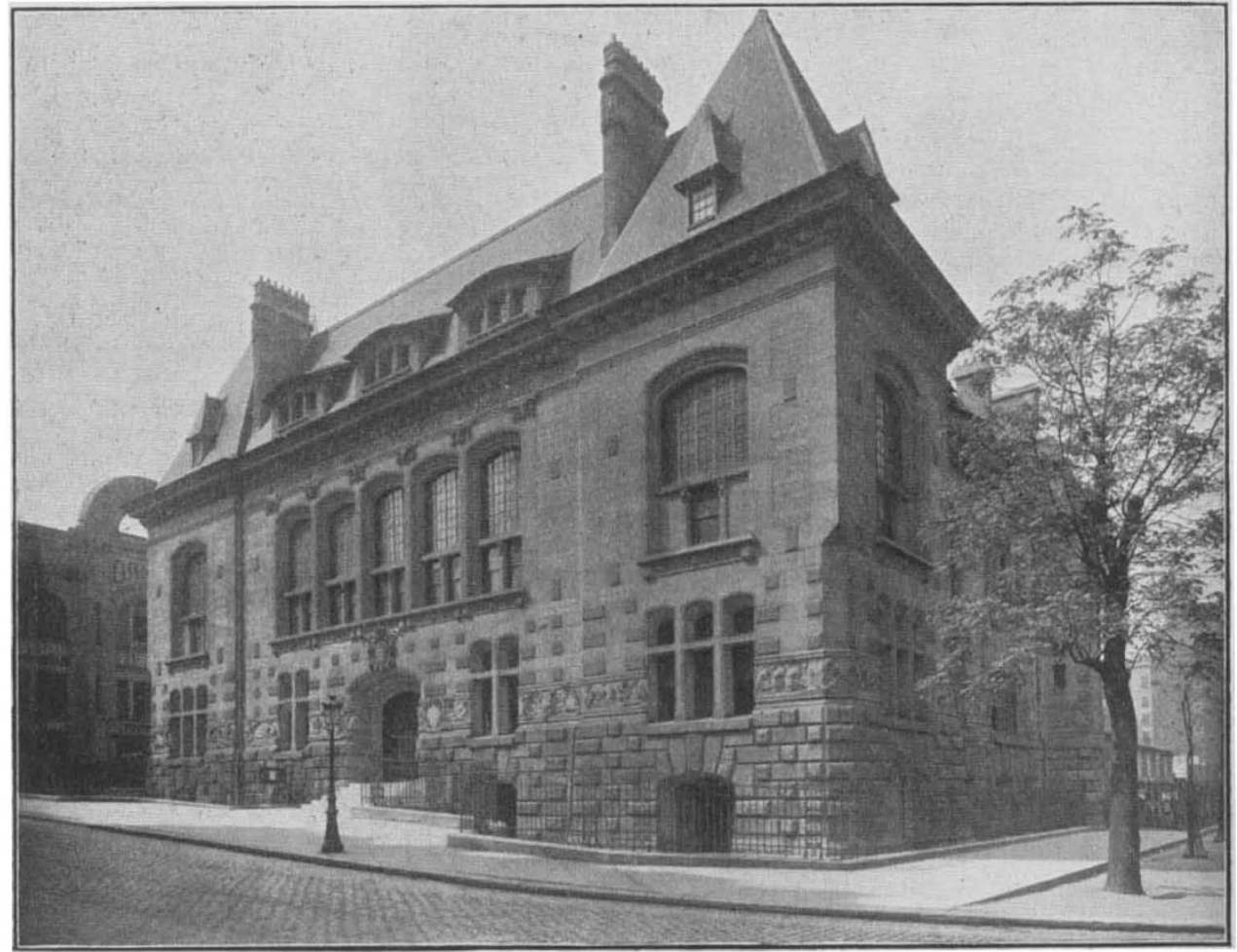

FIG. x.-The Institute of Human Palæontology. Front elevation.

French archæologists to throw a flood of light on the character, art, life, and environment of prehistoric man, have been carried out under his auspices, at his expense, and frequently on lines suggested by him, while he has been responsible for the publication of the results in a manner and with a wealth of illustration which are not likely to be surpassed. Now, by the foundation of this institute as a headquarters in France for the systematic investigation of problems related to the origin and development of man, the Prince of Monaco has ensured the prosecution of this branch of scientific research in the most favourable conditions.

The Institute of Human Palæontology is situated in the Boulevard Saint Marcel. The buildNO. 2674 , VOL. IO6] cost of living. The institute is under the direction of M. Marcelin Boule, assisted by a council consisting of MM. Saromon Reinach, Dislère, Verneau, and Louis Mayer.

Among those who were present at the opening ceremony were the President of the French Republic, M. Millerand, H.I.H. Prince Roland Bonaparte, M. Honnorat, then Minister of Public Instruction, the Belgian and Italian Ambassadors, the Argentine and Persian Ministers, M. Lacroix, secretary of the Academy of Sciences, the president of the Academy of Medicine, and representatives of the College of Medicine, the Collège de France, the Pasteur Institute, and the various scientific societies. 
An inaugural address was delivered by the Prince of Monaco, in which he defined eloquently the broad aims of human palæontology. It was, plaything in the hands of the forces of Nature; on the other, it helped us to surmount the bounds of a narrow philosophy which would reject all

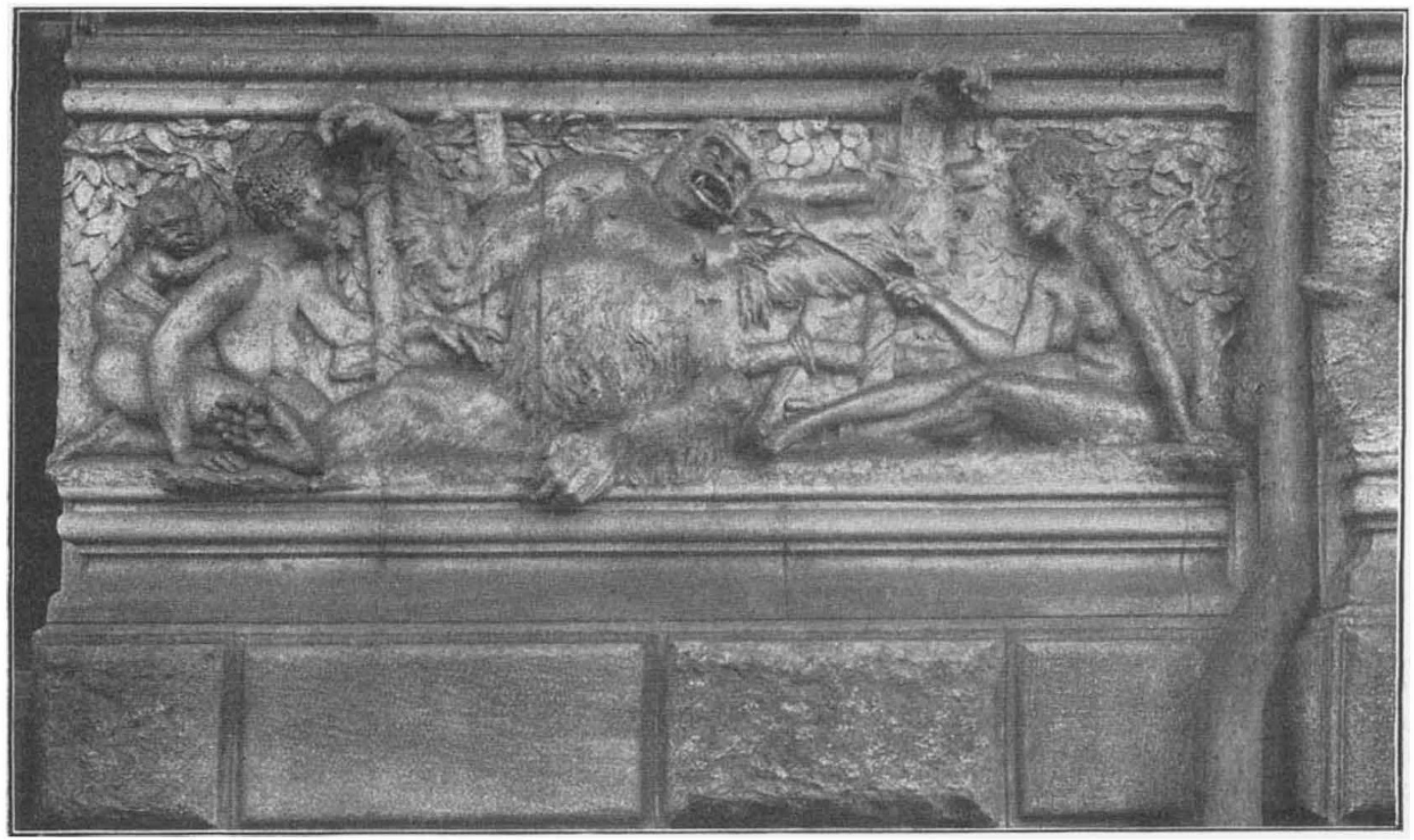

Fig. 2.-The Institute of Human Palæontology. Sculptured group. Negresses and dead orang.utan.

he said, the prehistory of humanity. Only a few years had elapsed since men of science had recognised human handiwork in flints embedded in geological strata, and had seen in them man's first attempts at fashioning weapons for the chase and for defence. On these stones had been based a science which revealed our past and freed our judgment from the power of baseless philosophies and superstition. Investigation which traced the human species back to remote epochs revealed its relation to the animal world, from which it seemed slowly to have evolved. The prehistory of man began at that point when the human family was distinguished from other animals by a development of the brain which enabled it to diminish the part played by the muscles, and to employ moral force to carry on the struggle for existence: an artificial weapon took the place of the natural weapon, while, as shown by the paintings and drawings of the caves of Spain and Southern France, man was already capable of æsthetic emotion and sentiment.

The lesson of the history of mankind was, on the one hand, that man, though favoured by the laws of the universe, was still nothing more than a NO. 2674, VOL. IO6] idea of relationship between man and the other members of the living world, and would wish to debar us from a study which placed mankind in

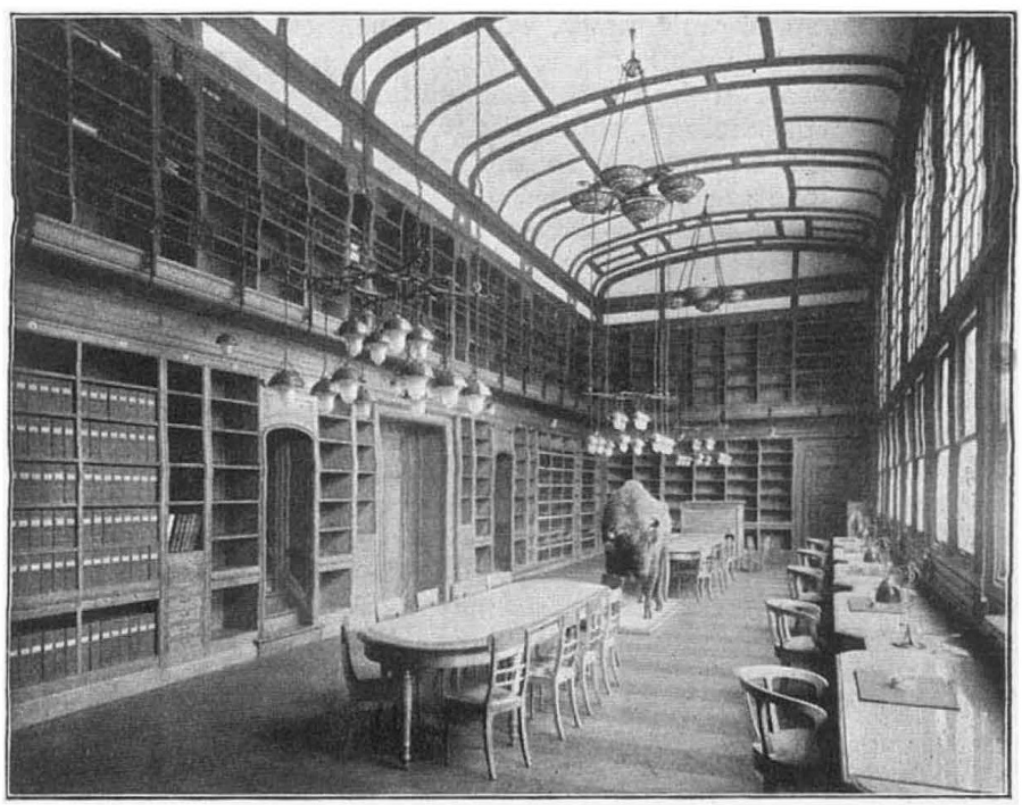
FIG. 3.-The Institute of Human Palæontology. View of library showing bison killed by the an appropriate rank in the life of the globe. In the Prince's own words: "C'est pour aider l'Anthropologie à franchir les barrières qui la 
séparent de la vérité complète que je fonde 1'Institut de Paléontologie humaine en lui donnant toute l'indépendance nécessaire pour conduire notre esprit vers la lumière. Et je confie ses interêts à des hommes qui servent la Science avec une sincérité capable de développer sa force et de protéger sa marche contre l'influence des interventions passionnées."

At the conclusion of the Prince's address, brief speeches were made by M. Honnorat, Minister of Public Instruction, M. Perrier, and M. Le Corbeiller, president of the Municipal Council, the last named speaking on behalf of the city of Paris. Lastly, M. E. Cartailhac, the veteran archæologist, expressed his joy at the creation of the institute, which, he said, had been his dearest wish throughout his career as an archæologist.

The Institute of Human Palæontology is the materialisation of a conception of the aims and methods of prehistoric archæology formed by the Prince of Monaco when first he turned serious attention to the subject. It is, in a sense, a pendant to the institute he has founded for the study of oceanography, for, as he said in his inaugural address, "L'Océanographie, qui embrasse les origines du Monde, m'a rapproché de 1'Anthropologie qui renferme les plus profonds secrets de l'Humanité." The reward which the Prince will seek for his munificent benefaction will lie in the results which may be expected from the facilities for study and research which he has placed at the disposal of science; but this reward will in itself be only a further addition to the debt already owed to him by archæology. His Serene Highness Prince Albert has indeed erected "a monument more lasting than brass."

\section{Obituary.}

\section{Dr. J. B. CROZIER.}

$D^{R}$ R. JOHN BEATTIE CROZIER (born at Galt, Canada, on April 23, 1849; died in London on January 8) was a thinker who knew how to combine philosophic breadth with scientific substance. His first master in speculative thought was Herbert Spencer, but he soon began to deviate from what he took to be the materialistic outcome of Spencer's psychology. The fault he found was that Spencer, in investigating mind, failed to view it adequately except from the objective side, as correlated with the brain and nervous system. This correlation itself Crozier accepted in the most thoroughgoing way; but, as the body is an organic unity, so also, he held, must the mind be unitary; and, by introspection, he found a "scale in the mind," not unlike that of the Platonic psychology, though it was for him an independent discovery. In this scale, truth, beauty, and love are at the top; such feelings as honour, ambition, and self-respect in the middle; and such qualities as greed and, in general, animal appetite at the bottom. This led Crozier to a metaphysical doctrine (though he was inclined to repudiate the term metaphysics) according to which the higher attributes of mind are superior not only in quality, but also, correspondingly, in ultimate strength.

What this scale or order in the mind points to, though it does not actually prove it, is dominance of the universe by a Supreme Intelligence. This view Crozier arrived at early, as may be seen in some extremely interesting chapters of "My Inner Life" (1898), and preserved to the end, as is set forth in "Last Words on Great Issues" (I9I7). It did not amount, he frankly admitted, to a religious creed. Having no mystical turn, he set to work in a scientific spirit on the investigation of human history, where, if anywhere, verification might be expected. The clue was the newly demonstrated theory of biological evolution, in which his master was Darwin. In the history of civilised peoples, on a wide survey, he found NO. 2674 , VOL. IO6] laws of progress; and these he made it his purpose to bring out in his central and best-known work, "The History of Intellectual Development."

In this and his other books, which grouped themselves naturally around it, Crozier carried out with approximate completeness, with literary interest diffused over the whole, and in the end with considerable acceptance on the part of the public, the scheme he had set before himself in the beginning. Presiding over his studies of historical evolution was his other great leading idea, that of social consensus-no doubt more vividly realised through his occupation with the profession of medicine. As the individual mind, like the body, is an organic whole, so is a society considered mentally as well as in its physical interconnection; and, apart from society, the individual is unintelligible.

Quite rightly, in his latest book, Crozier claims to have anticipated much recent development of a general theory which he had already styled the "doctrine of the herd." His versatility went along with a capacity for close study and a gift of illumining social observation; and where he was not an expert he was ready to be corrected by experts.

By the death of Mr. Edmund J. Spitta on January $2 \mathrm{I}$, at sixty-eight years of age, microscopical science has lost another earnest student and exponent. While in general medical practice for many years, Mr. Spitta found time to contribute to more than one branch of microscopy, and his retirement to Hove several years ago enabled him to devote the remaining years of his life to the subject. He took an active part in the proceedings of the Quekett Microscopical Club, of which he was a past-president, and of the Royal Microscopical Society, of which, as well as of the Royal Astronomical Society, he was a past vice-president. Mr. Spitta made some contributions to the subject of pond life, but it was particularly photomicrography and 